NR 19 (28)

BIBLIOTEKA

2015 PL ISSN 1506-3615

$\begin{array}{llllllll}A & R & T & Y & K & \text { U } & \text { E } & \text { Y }\end{array}$

ANNA SOBCZAK

Uniwersytet im. Adama Mickiewicza w Poznaniu, studentka Katedry Muzykologii

\title{
Graduał rkp 7021 Biblioteki Uniwersyteckiej w Poznaniu jako przykład recepcji potrydenckiej reformy chorału gregoriańskiego w polskim obrządku liturgicznym
}

Streszczenie. Graduał rkp 7021 Biblioteki Uniwersyteckiej w Poznaniu jest jednym z wczesnych przykładów recepcji potrydenckiej reformy chorału gregoriańskiego na terenie XVII-wiecznej Rzeczypospolitej. Księga pochodzi z toruńskiego skryptorium benedyktynek kongregacji chełmińskiej.

Celem artykułu jest ukazanie przemian liturgicznych, jakie zaszły w Rzeczypospolitej na początku XVII wieku, na przykładzie analizy zawartości rękopisu benedyktynek i innych dostępnych źródeł, a także nakreślenie problemu reformy repertuaru gregoriańskiego wprowadzonego przez Stolicę Apostolską i jego polskiej recepcji.

Dla liturgii Kościoła zachodniego najważniejszym osiągnięciem reformy potrydenckiej było ujednolicenie ksiąg liturgicznych, co prowadziło do unifikacji liturgicznej całego Kościoła. W Rzeczypospolitej przyjęto brewiarz i mszał rzymski oraz mające $z$ nimi ścisły związek - antyfonarz i graduał. W księgach tych starano się jednak zachowywać tradycje lokalne, co nie pozwoliło na całkowite przyjęcie rytu rzymskiego. Graduał rkp 7021 BUAM pochodzący z toruńskiego skryptorium zakonu benedyktynek kongregacji chełmińskiej i będący przykładem wprowadzania przez zakonnice reformy trydenckiej na terenie XVII-wiecznej Rzeczypospolitej nie ma powiązania z tradycją lokalną czy zakonną.

W historii recepcji reformy trydenckiej na terenie Rzeczypospolitej benedyktynki kongregacji chełmińskiej mają niewątpliwie wiele zasług. Odcinając się od reguły benedyktynów tynieckich i tworząc własna, opartą na postanowieniach soboru trydenckiego, okazały się zakonem nowatorskim i atrakcyjnym. Nie bez znaczenia jest tu ich współpraca z zakonem jezuickim, który był również propagatorem reformy liturgicznej.

Artykuł ukazuje, jak ważne są badania polskich źródeł muzyczno-liturgicznych okresu potrydenckiego. Stanowi też ważny wkład w rozpoznanie i opisanie źródła, które do tej pory nie było powszechnie znane. 
SŁowA KLUCzowe: graduał, reforma trydencka, sobór trydencki, chorał gregoriański, Kościół katolicki, liturgia Kościoła katolickiego, ryt, antyfonarz, mszał, brewiarz, Piotrkowczyk, benedyktynki kongregacji chełmińskiej, rękopis, XVII wiek.

Rękopiśmienny graduał znajdujący się w Zbiorach Specjalnych Biblioteki Uniwersyteckiej w Poznaniu (sygnatura lokalna: rkp 7021) to pozycja, która nie została do tej pory opisana. Jest to jedna z wcześniejszych ksiąg stworzonych w związku z przemianami liturgicznymi, jakie nastąpiły po soborze trydenckim (1545-1563) w Rzeczypospolitej. Jest doskonałym przykładem przyjęcia rytu rzymskiego w polskim obrządku liturgicznym, ponieważ została spisana w toruńskim skryptorium zakonu benedyktynek kongregacji chełmińskiej, który powstał wskutek reformy trydenckiej.

Ogólny stan badań nad tematyką trydenckiej reformy liturgicznej w Rzeczypospolitej jest dobry. Zachowało się wiele źródeł, opisanych już w literaturze. W bibliotekach i archiwach przechowywanych jest wiele ksiąg liturgicznych, drukowanych i rękopiśmiennych, zarówno z tradycji diecezjalnej, jak i z tradycji zakonnej ${ }^{1}$. Dzięki temu wiedza na temat rytu rzymskiego na terenie Polski nie ma charakteru stricte historycznego ${ }^{2}$. Wiele także wiadomo o samym soborze trydenckim i o problemach podejmowanych na obradach. Mało wspominano wówczas o muzyce samej

${ }^{1}$ Eucharystię w rycie rzymskim przestano sprawować w Kościele katolickim dopiero po soborze watykańskim II (1962-1965). Obecnie odprawiane są msze święte w tzw. rycie nadzwyczajnym. Jest to powrót do mszy trydenckiej, który jest praktykowany przez Nowy Ruch Liturgiczny.

${ }^{2} \mathrm{~W}$ artykule oparto się głównie na publikacji Ireneusza Pawlaka Graduaty piotrkowskie jako przekaz chorału gregoriańskiego po soborze trydenckim (Lublin 1988). W pierwszej części autor opisał uchwały soboru trydenckiego dotyczące liturgii, reformę chorału gregoriańskiego oraz przyjęcie dekretów tridentinum w Polsce. Druga część traktuje o historii oficyny Piotrkowczyków i prezentuje graduały będące przedmiotem badań autora. W części trzeciej znajduje się studium tekstów oraz badania nad melodiami gregoriańskimi. W opisie fizycznym rękopisu oparto się na pracy Pawła Gancarczyka Musica scripto. Kodeksy menzuralne II połowy XV wieku na wschodzie Europy Łacińskiej (Warszawa 2001). W opisie historii chorału gregoriańskiego i graduału jako księgi liturgicznej powołano się na podręcznik Wydawnictwa Dębogóra Laus in Ecclesia. Szkoła śpiewu gregoriańskiego (Dębogóra 2013) oraz na publikację Iwo Huberta Siekierki Notacja sangalleńska i metzeńska jako wspótczesne źródło interpretacji chorału gregoriańskiego (Opole 2005). Ważne źródło stanowiły także dwie pozycje Pawła Sczanieckiego: Msza po staremu się odprawia (Kraków 1967) oraz Służba Boża w dawnej Polsce (Poznań 1966). Do opisu środowiska powstania rękopisu wykorzystano pracę Magdaleny Walter-Mazur Figura i fraktem. Kultura muzyczna polskich benedyktynek w XVII i XVIII wieku (Poznań 2014). Z publikacji Bożeny Stelmachowskiej Sztuka ludowa na Kaszubach zaczerpnięto informację do opisu zdobień graduału. 
w sobie, skoro jednak stanowiła ona integralną część liturgii, którą w wielu aspektach poddano reformie, w końcu należało wprowadzić zmiany również w muzycznej części ceremonii kościelnych.

\section{Sobór trydencki (1545-1563) i reforma liturgii zachodniej Główne uchwały soboru trydenckiego dotyczące liturgii Kościoła zachodniego}

Sobór trydencki, zwołany przez papieża Pawła $\mathrm{III}^{3}$, poruszał głównie problemy herezji i dogmatów teologicznych. Jego celem było podjęcie działań kontrreformacyjnych mających przeciwdziałać herezji i ruchom reformacyjnym. Ówczesne przemiany w Kościele zachodnim dotyczyły wielu aspektów życia religijnego, m.in. liturgii.

Próby ujednolicenia liturgii i sprowadzenia jej wielu odmian do jednego wzoru, czyli liturgii rzymskiej, której ramy ukształtowały się w XIII wieku, pojawiały się już przed soborem4. Znaczne różnice zauważyć można w układzie kalendarza liturgicznego i w zawartości ksiąg liturgicznych, zarówno rękopisów, jak i druków. Do braku jedności Kościoła w zakresie liturgii przyczyniały się też zwyczaje lokalne i dowolności, na jakie pozwalali sobie celebransi ${ }^{5}$.

Podczas sesji tridentinum poruszano tematy związane $\mathrm{z}$ odnową liturgiczną, omawiano zagadnienia dotyczące kanonu Pisma Świętego, grzechu pierworodnego i jego usprawiedliwienia oraz teologicznego znaczenia sakramentów ${ }^{6}$. W zakresie liturgii zmiany dotyczyły m.in. wprowadzenia nowego kalendarza liturgicznego czy zreformowanych ksiąg, takich jak mszał czy brewiarz.

\section{Reforma chorału gregoriańskiego po soborze trydenckim}

Z posoborową odnową liturgiczną nastąpiła również reforma chorału gregoriańskiego, ponieważ był on zawsze ściśle związany z tekstami i obrzędami liturgicznymi ${ }^{7}$. Równolegle z nową edycją mszału i brewia-

${ }^{3}$ Zob. http://soborowa.strefa.pl/code-21/ [dostęp: 12.03.2014].

${ }^{4}$ I. Pawlak, op.cit., s. 15.

5 Ibidem, s. 16.

${ }^{6}$ Ibidem.

7 Zagadnienia dotyczące reformy chorału gregoriańskiego po soborze trydenckim za: I. Pawlak, op.cit., s. 31-33, 40-44, 46. 
rza wydawano poprawione księgi zawierające śpiewy przeznaczone do wykonywania oficjów lub mszy.

Przed soborem podstawową księgą zawierającą teksty i melodie antyfon oraz responsoriów oficjum liturgii godzin był antyfonarz. Wiadomo, że repertuar średniowiecznych antyfonarzy był zróżnicowany. Zawarte $\mathrm{w}$ nich teksty i melodie reprezentowały różne tradycje, zarówno zakonne, jak i diecezjalne, a także odmienne dla danych państw czy regionów. Kolejną grupę ksiąg stanowiły graduały, w których początkowo umieszczano śpiewy proprium missae, a z czasem zaczęto uzupełniać je o melodie ordinarium missae. Dalej należy wymienić pontyfikał, który był przeznaczony do czynności biskupich, oraz mniejsze księgi, takie jak: psałterze, procesjonały i agendy przedtrydenckie. Działalność papieży posoborowych znacznie ograniczyła liczbę wyżej wymienionych ksiąg, nastąpił też proces ich unifikacji, czemu impuls dała zmiana w układzie brewiarza i mszału.

Kwestia muzyki kościelnej została poruszona podczas soboru tylko raz, na sesji XXII, za papieża Piusa IV, 17 września 1562 roku:

$\mathrm{Ab}$ ecclesiis vero musicas eas ubi sive organo sive cantu lascivum aut impurum aliquid miscetur item saeculares omnes actiones vana atque adeo profana colloquia deambulationes strepitus clamores arceant ut domus dei vere domus orationis esse videatur ac dici possit ${ }^{8}$.

Postulowano usunięcie wszelkiej muzyki mającej naleciałości świeckie. Prawdopodobnie zwrócono uwagę na muzykę wielogłosową. Można zatem postawić tezę, jak czyni to Ireneusz Pawlak, że w centrum muzyki liturgicznej został postawiony chorał gregoriański, jako jej wzorzec. Jednak, podobnie jak w przypadku zmian ściśle liturgicznych, reforma chorału nastąpiła dopiero po zakończeniu tridentinum.

Działania papieża Piusa V, polegające na wprowadzeniu nowego mszału' ${ }^{9}$, były bezpośrednim impulsem do zmian w księgach przeznaczonych do śpiewu, ponieważ nastąpiły modyfikacje w układzie celebracji oraz tekstów liturgicznych. Przede wszystkim wyeliminowano tropy

8 ,Z kościołów będą usunięte takie rodzaje muzyki, w których tkwi domieszka czegoś swawolnego albo nieczystego, czy to wykonywanej na organach, czy też śpiewanej, jak również wszelkie świeckie sprawy, próżne, a więc bezbożne spotkania, przechadzki, hałasy, krzyki, aby Dom Boży był naprawdę (i mógł być nazwany) domem modlitwy". Tłumaczenie za: http://soborowa.strefa.pl/code-21/ [dostęp: 3.04.2014].

${ }^{9}$ Konstytucja apostolska Quo primum tempore z 1570 roku, za: http://mszatrydencka.waw.pl/index.php/msza-trydencka/zrubryk [dostęp: 12.03.2014]. 
i sekwencje, uzupełniono brakujące teksty, a co za tym idzie - skomponowano do nich nowe melodie, zmieniono kolejność niektórych śpiewów zgodnie z nowym rytem, dostosowano proprium de sanctis do nowego kalendarza liturgicznego.

Odnowę chorału rozumiano $\mathrm{w}$ tamtym czasie dwojako: po pierwsze dążono do podniesienia kwalifikacji muzycznych kleru i lepszego opanowania oraz rozszerzenia repertuaru gregoriańskiego, po drugie szukano sposobu, jak przejrzeć i oczyścić tradycję chorałową zgodnie z panującymi ówcześnie zasadami humanizmu. Dla reformatorów źródłem odniesienia stały się przekazy Kościoła pierwotnego oraz Ojców Kościoła. Zadecydowano, że główne zmiany powinny nastąpić w terminologii, deklamacji tekstu i tonalności chorału.

W zakresie terminów powrócono do łaciny klasycznej, wyrażenia greckie zastąpiono łacińskimi, a notację kwadratową notacją gotycką. W deklamacji tekstu wprowadzono rozróżnienie między sylabami długimi a krótkimi; ważniejszy stał się tekst, do którego należało dostosować muzykę. Krytykowano obecny kształt melodii chorałowych i postulowano powrót do starożytności, ponieważ - jak ówcześnie sądzono - wtedy rozwinęła się prawdziwa sztuka. Uważano, że zrozumienie chorału zależy od poznania muzyki starożytnej.

Rzymska reforma chorału gregoriańskiego trwała kilka dziesięcioleci i przyczyniło się do niej trzech papieży. Pierwszym był papież Grzegorz XIII, którego pontyfikat trwał w latach 1572-1585. Otworzył on centralną drukarnię papieską Stamperia Orientale, od nazwiska kierującego nią kardynała Medici zwaną drukarnią medycejską. Tam właśnie drukowano zrewidowane księgi z poprawionymi melodiami ${ }^{10}$.

Drugim papieżem firmującym posoborową reformę chorału gregoriańskiego był Klemens VIII. Jego pontyfikat przypada na lata 1592-1605. Kongregacja Świętych Obrzędów 21 stycznia 1594 roku udzieliła drukarni medycejskiej przywileju na wyłączne drukowanie ksiąg ze śpiewami chorałowymi. Podjęto prace nad zrewidowaniem i wydaniem pontyfikału,

${ }^{10}$ W czasie pontyfikatu Grzegorza XIII pracę nad muzycznymi księgami liturgicznymi rozpoczęli Giovanni Pierluigi da Palestrina i Annibale Zoilo. Ich zadanie polegało na poprawieniu antyfonarzy, graduałów, psałterzy i innych mniejszych ksiąg. Swoje działania rozpoczęli od weryfikacji graduału. Palestrina pracował nad proprium de tempore, Zoilo nad proprium de sanctis. Dokonali oni przeróbki melodii chorałowych według założeń estetycznych, które miały zastosowanie w polifonii (E. Hinz, Chorat gregoriański, Pelplin 1999, s. 18). Były to zabiegi zubażające chorał gregoriański. Obaj kompozytorzy nie znali i nie wyczuwali stylu gregoriańskiego. W 1578 roku zakończono rewizję wszystkich śpiewów, jednak nowych ksiąg nie wydano ze względu na sprzeciw Filipa II, króla Hiszpanii. 
który wyszedł z drukarni 10 lutego 1596 roku pod nazwą Pontyfikale Romanum $^{11}$. Stolica apostolska nie wydała jednak zezwolenia na wydrukowanie graduału i antyfonarza - głównych ksiąg liturgicznych zawierających melodie chorałowe. Mimo to w Wenecji ukazały się, częściowo zredagowane m.in. przez Andreę Gabrielliego i Orazia Vecchiego, dwa antyfonarze: pierwszy w 1590 roku, drugi sześć lat później. Były to dwa wydania tego samego antyfonarza.

Ostatni etap reformy przypada na lata 1605-1621. Są to lata pontyfikatu papieża Pawła V, który 28 sierpnia 1608 roku powołał specjalną komisję do spraw reformy chorału. Kontynuacją prac nad graduałem zajęli się: kardynał del Monte, Francesco Anerio i Francesco Soriano. W 1612 roku komisja przedstawiła gotowy do druku rękopis, który wydano w dwóch częściach: pierwszą proprium de tempore, zatytułowaną Dominicale, w 1614 roku; druga, proprium de sanctis, zatytułowaną Sanctuarium - rok później ${ }^{12}$.

Nowy graduał był popularnie nazywany editio medicea, ponieważ został wydany w drukarni medycejskiej. Melodie zawarte w księdze były podporządkowane nowym zasadom: skracano melizmaty, co uważano za oczyszczenie chorału z niepotrzebnych naleciałości, w melizmaty zaopatrywano tylko sylaby akcentowane ${ }^{13}$. Jeśli jeden tekst był wykonywany w różnych miejscach liturgii, ujednolicano przebieg wyrazów w tym tekście oraz obudowywano je takimi samymi zwrotami melodycznymi. Poprawiono formuły inicjalne. Ambitus, materiał tonalny melodii, cezury i kadencje dostosowano do zasad kompozytorskich panujących w XVI wieku.

Editio medicea jest uznawane za punkt szczytowy rzymskiej reformy chorału. Wydanie to nie było nigdy oficjalne. Mimo iż wydawca Raimondi opatrzył je inskrypcją: "Paulo iussu reformata”, zawsze pozostało edycją prywatną ${ }^{14}$. Jednak przeprowadzone w nim zmiany i oczyszczenia melodii wywarły ogromny wpływ na kolejne wydania graduału. Melodie śpiewów lokalnych zawartych w owych księgach weryfikowano według tych samych zasad, którymi kierowali się twórcy editio medicea.

W głównych działach liturgia i śpiew chorałowy zostały zreformowane dopiero po prawie 40 latach od zakończenia soboru. Proces recepcji tych zmian trwał jednak o wiele dłużej.

\footnotetext{
${ }^{11}$ Skrócono w nim melizmaty oraz uwzględniono akcenty łaciny klasycznej.

12 E. Hinz, op.cit., s. 19.

13 Dotyczyło to głównie graduale i śpiewów allelujatycznych.

${ }^{14}$ Ibidem, s. 20.
} 


\section{Recepcja reformy potrydenckiej na terenie Rzeczypospolitej}

W Polsce zmiany zapoczątkował synod piotrkowski, który rozpoczął obrady 19 maja 1577 roku $^{15}$. Już jednak w roku 1564 na sejm do Parczewa przybył nuncjusz papieski Giovanni Francesco Commendone. Tam spotkał się z ówcześnie panującym królem Zygmuntem Augustem oraz kardynałem Stanisławem Hozjuszem, który był przedstawicielem prowincji polskiej na soborze trydenckim ${ }^{16}$. Commendone przedstawił uchwały soborowe, które przyjął król i senat. Mimo to episkopat nie od razu zaakceptował postanowienia tridentinum. Dopiero za sprawą synodu w Piotrkowie zainaugurowanego przez bpa Jana Uchańskiego 19 maja 1577 roku biskupi przyjęli uchwały soboru ${ }^{17}$. W dokumentach synodalnych, w artykule XXIV widnieje następujący zapis:

Tenże synod św. przyjął dla użytku prowincji tej mszały i brewiarze rzymskie, z polecenia św. synodu trydenckiego spisane i wydane, ażeby usunąć różnice $\mathrm{w}$ modlitwach i śpiewie kościelnym ${ }^{18}$.

Skutkiem przyjęcia kanonów i dekretów soborowych była konieczność dostosowania graduału i antyfonarza do nowego rytu. Księgi te miały zostać sporządzone na wzór wydań rzymskich. To samo dotyczyło brewiarza i mszału ${ }^{19}$. Wprowadzane reformy wciąż ścierały się z głęboko zakorzenioną rodzimą tradycją. Niechęć polskiego Kościoła do zmian znalazła oddźwięk w komedii rybałtowskiej Synod klechów podgórskich (1633):

Dobreć były za naszych urzędów chorały,

Jużeśmy i na pamięć umieli gradały.

Teraz jakieś gradały nowe wymyślili,

Leda by nam staruszkom złości naczynili,

A tak nam dogodzili tymi gradałami,

że musim zaś znowu być gregoriankami ${ }^{20}$.

W liście pasterskim, znanym jako Epistola pastoralis ad parochos, biskup gnieźnieński Bernard Maciejowski wyraził aprobatę dla postulatów

15 Ibidem, s. 56.

${ }^{16}$ Ibidem, s. 137.

${ }^{17}$ I. Pawlak, op.cit., s. 56.

${ }^{18}$ Cyt. za: W. Gieburowski, Chorat gregorjański w Polsce od XV do XVII wieku ze specjalnym uwzględnieniem tradycji i reformy oraz choratu piotrkowskiego, Poznań 1992, s. 62.

19 I. Pawlak, op.cit., s. 56.

${ }^{20}$ J. Bobrowska, Kultura muzyczna w świetle literatury staropolskiej XVI i XVII wieku, „Muzyka” 1977, nr 2, s. 42. 
soboru, jednocześnie wziął pod uwagę potrzeby polskiego Kościoła ${ }^{21}$. W 1621 roku prymas Wawrzyniec Gembicki zwrócił uwagę, że niejednolitość śpiewów w graduałach, antyfonarzach i psałterzach utrudnia należyte sprawowanie oficjów i mszy. Biskupi zlecili rewizję i ponowne wydanie owych ksiąg, zobowiązując się do pokrycia kosztów druku oraz do rozesłania ich za darmo wszystkim proboszczom ${ }^{22}$. W kolejnych latach podejmowano jeszcze wielokrotne rewizje i dodruki ksiąg liturgicznych, ponieważ zapotrzebowanie na nie wciąż rosło. W roku 1628 Andrzej Piotrkowczyk junior został ustanowiony drukarzem kościelnym. W jego oficynie ukazały się antyfonarze, graduały i rytuały ${ }^{23}$ :

[Księgi te miały - A.S.] zachować pobożne i chwalebne zwyczaje polskie, o ile nauka i przepisy soboru trydenckiego na to pozwalają ${ }^{24}$.

Działalność oficyny rozpoczął w 1570 roku w Krakowie Andrzej Piotrkowczyk senior ${ }^{25}$. W 1589 roku tytuł drukarza kościelnego otrzymał na synodzie piotrkowskim Januszowski. Mimo to w 1599 roku Piotrkowczyk wydał pierwsze dzieło liturgiczne - Psalterium - które było dostosowane do reformy trydenckiej. Dzieło było dedykowane biskupowi krakowskiemu Jerzemu Radziwiłłowi i wydrukowane za jego zgodą. Rok później w oficynie ukazały się kolejne zreformowane księgi liturgiczne: Antiphonale i Graduale. Ostatnie wydawnictwa Andrzeja Piotrkowczyka seniora to Antiphonale (1607) i Graduale (1614). Po jego śmierci (1620) pieczę nad drukarnią sprawował zięć seniora - Tomasz Dolabella - aż do momentu, w którym przejął ją Andrzej Piotrkowczyk junior. Jako drukarz kościelny wydał bardzo wiele pozycji liturgicznych ${ }^{26}$. Po śmierci Andrzeja Piotrkowczyka juniora opiekę nad oficyną przejęła jego żona - Anna Teresa Piotrkowczykowa. W pracy pomagał jej syn Stanisław Teodor. W 1645 roku ukazało się poprawione wydanie Antiphonale, w 1647 roku Rituale oraz w roku 1651 Graduale. Po śmierci matki prace wydawnicze

${ }^{21}$ Ibidem, s. 586.

${ }^{22}$ I. Pawlak, op.cit., s. 59.

${ }^{23}$ Ibidem, s. 60.

${ }^{24}$ B. Izbicki, Trzy bitwy o chorat gregoriański, http://www.academia.edu/6219818/ Trzy_bitwy_o_choral_gregorianski [dostęp: 12.03.2014].

${ }^{25}$ Wszystkie zagadnienia dotyczące działalności wydawniczej Piotrkowczyków za: I. Pawlak, op.cit., passim.

${ }^{26}$ Do najważniejszych należą: patronał mszalny (1621), mszał żałobny, nowe opracowanie Graduale (1629) oraz Rituale sacramentorum (1631), które powstało na wzór Rituale romanum wydanego w Rzymie w 1614 roku na polecenie Pawła V (W. Gieburowski, op.cit., s. 68). 
prowadził dalej Stanisław Teodor Piotrkowczyk. To on wydał ostatnie księgi liturgiczne, które wyszły z oficyny Piotrkowczyków: Missae pro defunctis (1668), Rituale (1671) i Missae sanctorum (1672). Piotrkowczykowie wydali cztery graduały: w 1600, 1614, 1629 i 1651 roku. Graduale, które ukazało się z datą 4 listopada 1600 roku, było pierwszym wydaniem Graduale romanum w Rzeczypospolitej.

Mimo zgody na przyjęcie reformy na terenie Rzeczypospolitej polski kler mocno akcentował potrzebę zachowania ojczystych tradycji w liturgii, takich jak zachowanie zwyczaju codziennej wotywy adwentowej czy ludowego refrenu „Przez twoje święte Zmartwychwstanie” w sekwencji wielkanocnej Victime paschali laudes ${ }^{27}$.

Ogólny zarys recepcji reformy liturgicznej w Rzeczypospolitej przełomu XVI i XVII wieku ukazuje z jednej strony, po początkowym sprzeciwie episkopatu, chęć polskiego Kościoła do wprowadzania zmian, z drugiejprzywiązanie do tradycji. Starania o jej zachowanie przy jednoczesnej odnowie liturgicznej doprowadziły w końcu do zaakceptowania rytu rzymskiego w całym kraju. Graduał rkp 7021 jest jednym z wczesnych przykładów owych przemian.

\section{Graduał rkp 7021 Biblioteki Uniwersyteckiej w Poznaniu}

\section{Środowisko powstania rękopisu}

$\mathrm{Z}$ inskrypcji na karcie tytułowej graduału rkp $7021^{28}$ wiadomo, że powstał on w Toruniu, w klasztorze benedyktynek kongregacji chełmińskiej. Był to drugi, po chełmińskim, klasztor w Rzeczypospolitej zreformowany według zaleceń soboru trydenckiego.

W roku 1578 do opustoszałego po okresie reformacji klasztoru w Chełmnie wstąpiła Magdalena Mortęska (1554-1631), późniejsza reformatorka zakonu benedyktynek. W 1579 roku została ksienią. W 1605 roku przygotowała nową regułę zakonu, która została wydana w Lublinie 30 lat później. Mortęska poświęciła w niej wiele miejsca kwestii muzyki w liturgii. Dołączyła też do niej program nauczania dziewcząt w szkole przyklasztornej i formacji nowicjuszek. Reguła nie została chętnie przyjęta przez klasztor w Toruniu, którego ksieni - Zofia Dulska, wychowanka Mortęskiej - chciała doprowadzić do wydania własnej. Dopiero po śmierci obu ksień, w roku 1631, ustały spory między klasztorami chełmińskim i toruńskim. Oba klasztory były budowane od podstaw. Nowe

${ }^{27}$ P. Sczaniecki, Stużba Boża..., s. 143.

28 „in Conventu Torunensi ad laudem et gloriam Sanctissime Trinitatis”. 
benedyktynki nie czuły potrzeby powrotu do wymarłej niemal tradycji swoich poprzedniczek, bez oporów więc przyjęły w liturgii zreformowany mszał rzymski.

W 1599 roku na ksienię w Toruniu została konsekrowana Zofia Dulska. Dzięki jej talentom organizacyjnym i gospodarczym klasztor bardzo się rozwinął. Dbała ona też o rozwój muzyczny panien. Wiadomo, że dziewczęta wstępujące do postulatu w Toruniu uczyły się czytać i śpiewać, w ten sposób przygotowywały się do nowicjatu. Ważnym wydarzeniem w życiu klasztoru była wizyta królowej Konstancji Habsburżanki w 1632 roku. Kronikarka zapisała, że ksieni Dulska „poprowadziła ją po klasztorze i na chór, gdzie oględowała księgi do śpiewania i kwoli jej śpiewały siostry Te Deum Laudamus fraktem" ${ }^{29}$. Wskazuje to na bogactwo klasztoru w zakresie zarówno ksiąg liturgicznych, jak i umiejętności muzycznych zakonnic. Z Kroniki benedyktynek chetmińskich $^{30}$ wiadomo, że zakonnice bardzo dbały o wyposażenie swoich domów w odpowiednie księgi. Pierwsza wzmianka o księgach łacińskich pochodzi z 1582 roku i dotyczy zaopatrzenia nowego toruńskiego domu:

Posłano zaraz [do Torunia - A.S.] wielkie księgi notowane na pergaminie, graduał, w którym Msze były na Dominiki i na wszystkie święta przez rok ${ }^{31}$.

Kolejna informacja o graduale pochodzi z 1603 roku, kiedy posyłano benedyktynki do Zbysławia:

Każdej dano brewiarz, diurnał i oficjum P. Marii, księgi do śpiewania kościelnego, dwa graduały notowane, jeden na dominiki, a drugi na święta przez rok, 2 psałterze $\mathrm{z}$ wielkim drukiem, komunał stary notowany na pergaminie, mszał 1 drukowany i agendę stara, ksiąg pisanych i notowanych $2^{32}$.

Z tego samego roku pochodzi nota, iż do kościoła zakupiono „graduał z nutami do nauki nowicjuszkom" za 28 florenów ${ }^{33}$. Ostatnia informacja o graduałach jest datowana na 1611 rok, kiedy otwierano nowe domy zakonne we Lwowie i w Jarosławiu:

Wyprawa panien do Jarosławia i do Lwowa taka była: Naprzód ksiegi łacińskie: Graduały 2 z nutami na dominiki i święta przez rok. Psałterz z nutami 1. Brewiarzów nowego wydania 13. Oficjum Panny Marii 13. Litanijek łacińskich 3.

\footnotetext{
${ }^{29}$ M. Walter-Mazur, Figura i fraktem...

${ }^{30}$ W. Szołdrski, Kronika benedyktynek chetmińskich, Pelplin 1937.

31 Ibidem, s. 20.

32 Ibidem, s. 79.

${ }^{33}$ Ibidem, s. 80.
} 
Psałterzyk co wiersz łacińsku a wiersz polski. Patronów zakonu naszego wzięto $23^{34}$.

Benedyktynki nie szczędziły funduszy na wyposażanie swoich domów. Dbały, by w każdym z nich były nowe wydania ksiąg liturgicznych. Można przypuszczać, że wielokrotnie też je przepisywały dla własnych celów. W takich okolicznościach powstał rękopis znajdujący się obecnie w Zbiorach Specjalnych Biblioteki Uniwersyteckiej w Poznaniu.

\section{Cechy fizyczne rękopisu, datowanie i proweniencja}

Graduał rkp 7021 składa się z 283 kart o wymiarach 35 x 61 cm. Karty mają oryginalną błędną foliację rzymską umieszczoną u góry pośrodku karty $^{35}$. Według tej foliacji rękopis zawiera 259 kart.

Rękopis ma współczesną stylizowaną oprawę skórzaną o wymiarach $37 \times 65 \mathrm{~cm}$. Wewnątrz znajduje się kolorowa wklejka. Na karcie tytułowej widnieje następujący tekst:

Maria IHTS Maria / GRADUALE / Missarum omnium pro Dominicis per / annum: et festis solennibus Salvatoris nostri / Jesu Christi notarum: scrpitumve per $\mathrm{u} /$ nam de Virginibus Christo sacratis Moni / alem ordinis antiqui sancti Benedicti: in / Conventu Torunesi ad laudem et glori / am Sanctissime Trinitatis \& [et] cuttum [?] Dei / para sanctorumque omium anno Do / mini Millesimo sexcentesimo decimo / septimo / 18. D. Juliii ${ }^{36}$.

Znana jest więc dokładna data ukończenia rękopisu - 18 lipca 1617 roku. Jest to zatem księga tylko o dwa lata młodsza od opisywanej wcześniej medycejskiej edycji graduału. Z całą pewnością wiadomo też, że pochodzi

${ }^{34}$ Ibidem, s. 126-127.

${ }^{35}$ Po f. IX następuje f. XI; brak f. XX; zdwojone f. XXII, po którym następuje f. XXIIII; podwójne f. XCIII; brak f. CLVII, ale kolejna karta ma poprawny numer f. CLVIII, po niej następuje f. CLVIIII, a po niej f. CLIX; na karcie następującej po f. LCXIII widnieje trudny do odczytania numer, po czym powtarza się numeracja od CLX z pominięciem f. CLXII (dopisane ołówkiem arabskie 162), po f. CLXV następuje f. CLXVII, dwie karty mają numer CLXVIII; dwukrotnie pojawia się f. CLXXVIII; po f. CXCVIII kolejna karta to f. CXCIX; błędny zapis: zamiast CCXLIX zapisano CCXLIXI; po f. CCLIII następuje f. CCLV; po f. CCLXIII - f. CCLIIII, dalsze karty numerowane są kolejno (CCLIIII, CCLV etc.); po f. CCLVI następuje f. CCLVIII.

36 „Msze wszystkie na niedziele roku i uroczyste święta Zbawiciela naszego Jezusa Chrystusa przez jedną z Panien Chrystusowi poświęconą, zakonnicę z konwentu toruńskiego starożytnego zakonu świętego Benedykta, na cześć i chwałę Najświętszej Trójcy i jedynej Bogarodzicy i wszystkich świętych zapisane, roku pańskiego 1617, osiemnastego dnia lipca". Tłumaczenie: Anna Sobczak. 
ze skryptorium toruńskiego, podobnie jak dwa antyfonarze znajdujące się obecnie $\mathrm{w}$ archiwum klasztoru benedyktynek $\mathrm{w}$ Żarnowcu i drugi graduał należący do zbiorów Archiwum Diecezjalnego w Pelplinie.

Rękopis zachowany jest w bardzo dobrym stanie. Można przypuszczać, że nigdy nie był używany. Wskazuje na to stan kart rękopisu, na których nie ma zabrudzeń, zagięć ani innych śladów, charakterystycznych dla rękopisów często używanych.

\section{Cechy graficzne i notacyjne}

Graduał benedyktynek jest jednolity pod względem graficznym i notacyjnym. W całości został spisany przez jedną osobę, na co wskazuje wpis z karty tytułowej: „scriptuve per unam de Virginibus” („zapisane przez jedną z panien"). Potwierdza to także dukt pisma, który w całej księdze jest taki sam.

Śpiewy zapisane są bez wyjątku notacją kwadratową. W przebiegu znacznej większości melodii nie umieszczono znaków o charakterze interpretacyjnym, takich jak divisio ${ }^{37}$, epizema ${ }^{38}$, virgula ${ }^{39} \mathrm{czy} i k t u s^{40}$. Nie występują one również $\mathrm{w}$ editio medicea, $\mathrm{z}$ wyjątkiem divisio maior i divisio maxima. W paru miejscach pojawiają się one w poznańskim rękopisie, ale tylko w części ordinarium missae. Neumy nie zostały zróżnicowane pod względem rytmicznym, wszystkie mogą być określone jako punctum quadratum. W całości rękopisu dźwięki zapisane są na pięciolinii.

Teksty śpiewów chorałowych zanotowano czarnym inkaustem w stylu gotyckim. Niektóre litery inicjalne zaopatrzone zostały w iluminacje

${ }^{37}$ Pełni funkcję interpunkcji melodycznej, ma walor rytmiczny. Można wyróżnić cztery rodzaje divisio występujące w melodiach gregoriańskich: divisio minima - wskazuje koniec odcinka melodyczno-słownego i oznacza oddech, divisio minor - znak koniecznego oddechu, wyznacza koniec członu zdania melodycznego, divisio maior wskazuje zakończenie frazy melodycznej oraz divisio maxima - kreska podwójna, kończy całość śpiewu lub sygnalizuje zmianę grupy śpiewaków, jeśli utwór jest przeznaczony na dwie grupy. Za: I.H. Siekierka, op.cit., s. 21-22. Laus in Ecclesia..., s. $47-48$.

${ }^{38}$ Z greckiego oznacza „znak dodany”. W zapisie neumatycznym przyjmuje postać kreski pionowej (iktus) lub poziomej, która oznacza „oparcie” się na dźwięku, nad którym się znajduje. Za: Laus in Ecclesia..., s. 50.

${ }^{39}$ Graficznie przyjmuje postać przecinka umieszczonego na czwartej linii. Oznacza bardzo szybki oddech, który nie powinien naruszyć rytmicznej płynności melodii. Za: ibidem, s. 51.

${ }^{40}$ Oznacza jednocześnie początek miary i początek pulsu. Porównując go ze współczesnymi określeniami rytmicznymi, wyznacza „raz” w przebiegu melorytmicznym. Za: ibidem, s. 113. 
przedstawiające sceny z Ewangelii lub postaci świętych. Są to w większości inicjały do introitu niedzieli lub święta (il. 1, 2). Inicjały pozostałych śpiewów i wersetów na daną niedzielę są pozłacane lub zdobione motywami kwiatowymi i geometrycznymi. Najskromniejsze są monogramy z okresu Wielkiego Postu. Można przypuszczać, że w ten sposób chciano podkreślić ascezę tego czasu.

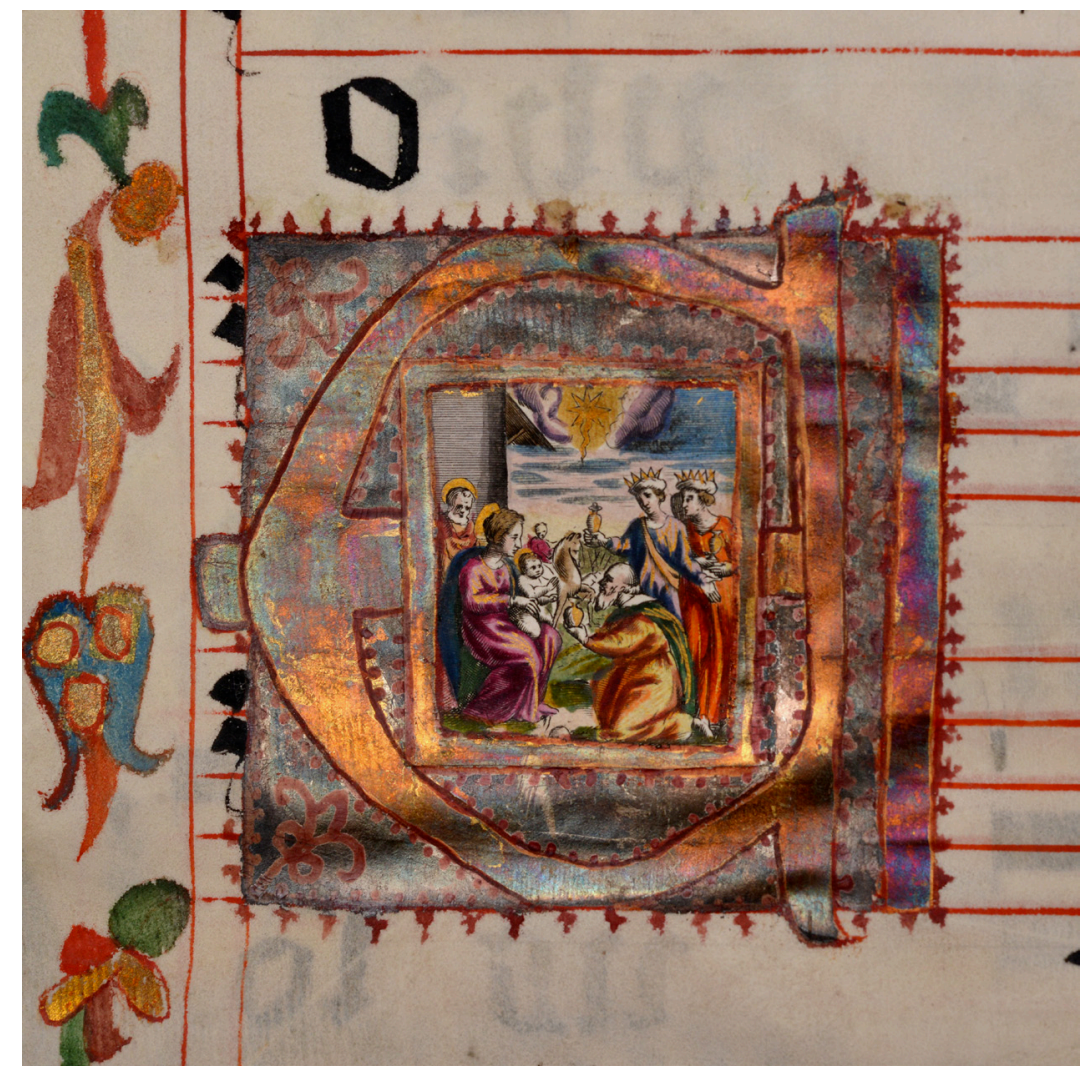

Il. 1. Inicjał z uroczystości Objawienia Pańskiego rozpoczynający introit: Ecce advenit dominator

Źródło: Biblioteka Uniwersytecka w Poznaniu, rpk 7021. Fot. Rafał Michałowski.

Czerwonym inkaustem oznaczono, na jaką niedzielę lub święto przypadają dane śpiewy. Wskazano, w którym miejscu rozpoczynają się introit, graduale, alleluja lub tractus, versus, offerta i communio, a także rubryki bardziej rozbudowanych celebracji, takich jak Triduum Paschalne.

Zdobienia graduału nasuwają skojarzenie z haftem kaszubskim. Wiadomo, że benedyktynki zajmowały się zdobieniem czepków, antependiów i szat liturgicznych: 


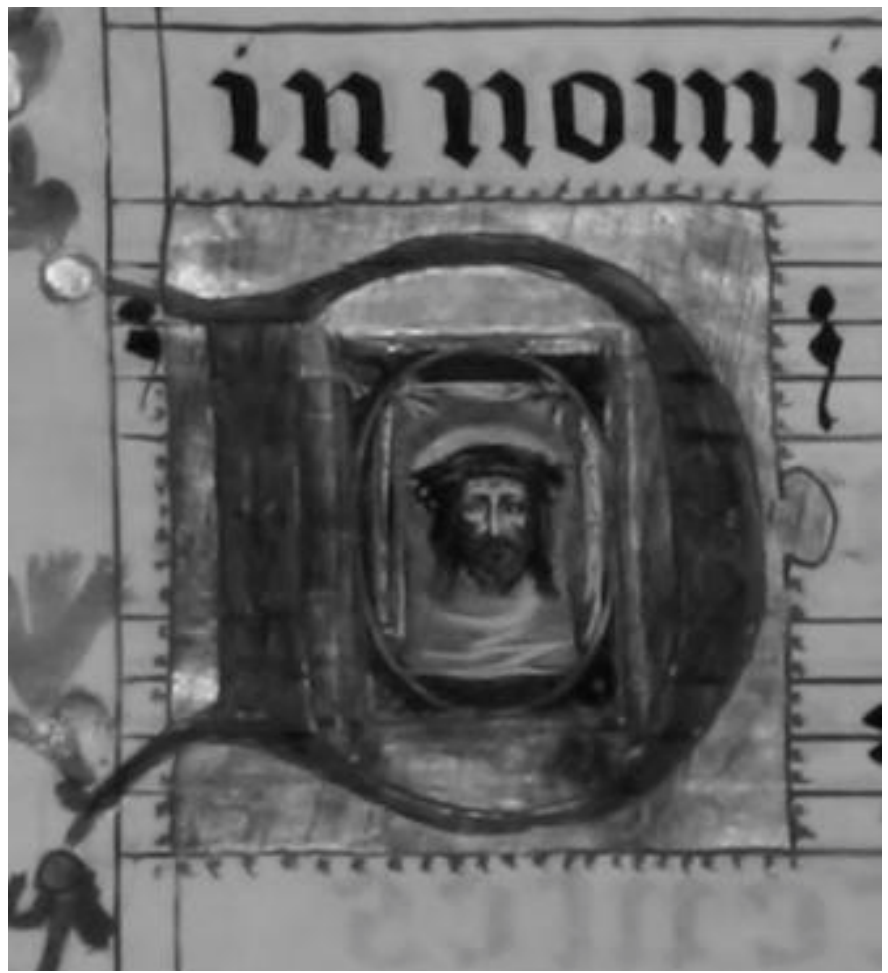

Il. 2. Inicjał z Niedzieli Palmowej rozpoczynający introit: Domine ne longe facias

Źródło: Biblioteka Uniwersytecka w Poznaniu, rpk 7021.

Głównemi warsztatami sztuki hafciarskiej były klasztory żeńskie, zwłaszcza Panien Norbertanek w Żukowie, w pow. kartuskim, oraz Benedyktynek w Żarnowcu, w pow. morskim ${ }^{41}$.

Motywy roślinne wywodzą się z haftu klasztornego kultywowanego przez wspomniane wyżej norbertanki i benedyktynki. Te z kolei, jak pisze Bożena Stelmachowska, czerpały wzornictwo z tkanin włoskich i francuskich pochodzących z XV, XVI i XVII wieku². Prawdopodobnie odrodzony w XX wieku haft kaszubski nawiązywał do tradycji hafciarskiej zakonnic, które uczyły robótek ręcznych świeckie panny przebywające w zakonnych szkołach.

Już na karcie tytułowej „poznańskiego” rękopisu znajduje się geometryczna kompozycja kwiatowa (il. 3), na którą składają się wzory

${ }^{41}$ B. Stelmachowska, op.cit., s. 55.

${ }^{42}$ M. Walter-Mazur, Figura i fraktem... 


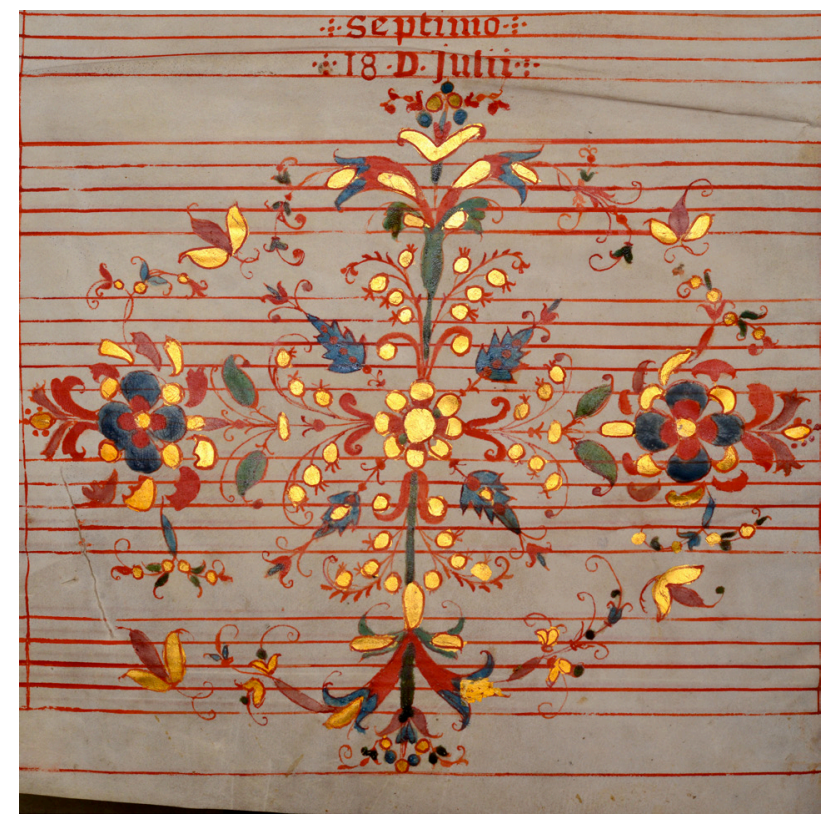

Il. 3. Kwiatowa kompozycja geometryczna z karty tytułowej Źródło: Biblioteka Uniwersytecka w Poznaniu, rpk 7021. Fot. Rafał Michałowski.

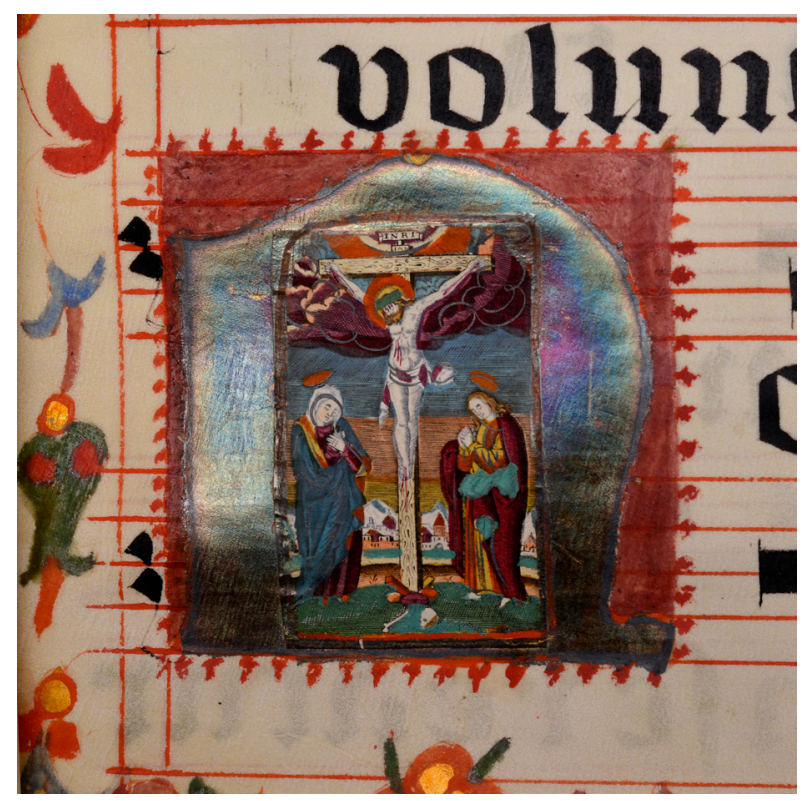

Il. 4. Inicjał z uroczystości Wielkiego Tygodnia rozpoczynający introit: Nos autem gloriari z widocznym bukietem w rogu strony Źródło: Biblioteka Uniwersytecka w Poznaniu, rpk 7021. Fot. Rafał Michałowski. 
tzw. wąsów, pąków, pszczółek, tulipanów, bratków, liści i owoców granatu. Są to główne ornamenty, które w pracy poświęconej sztuce ludowej Kaszub opisuje Stelmachowska. Pierwszym dominującym jest owoc granatu, drugim - tulipan. Oba motywy mają wiele odmian. Na dalszych kartach księgi pojawiają się także ornamenty gronowate, które prawdopodobnie nawiązują do religijnej symboliki krzewu winnego ${ }^{43}$. Występują również wspomniane wcześniej motywy geometryczne oraz kompozycje określane jako bukiet $\mathrm{w}$ rogach stron (il. 4).

Cały rękopis ozdobiony jest jednorodnie. Użyte kolory to granatowo-modry w różnych odcieniach, czerwień, zielony w tonacji oliwkowej, żółć, złoto i srebro. Są to barwy typowe dla haftu kaszubskiego ${ }^{44}$.

\section{Repertuar}

Graduał przedtrydencki był podzielony na trzy zasadnicze części. Pierwszą stanowiły śpiewy własne (proprium missae), które dzieliły się na śpiewy okresowe przypisane do danych okresów liturgicznych (Adwent, Wielki Post itp.) i śpiewy własne o świętych. W tej części zawarte były: introit, graduale, tractus, alleluja, sekwencja, offerta i communio. Druga część to śpiewy wspólne obejmujące msze ku czci świętych i msze wotywne. Ostatnią częścią były śpiewy stałe (ordinarium missae), czyli Kyrie, Gloria, Sanctus, Agnus i Credo ${ }^{45}$.

Po soborze trydenckim z proprium missae usunięto sekwencje i przeniesiono je do osobnej części graduału. Układ księgi potrydenckiej przedstawiał się zatem następująco: ordinarium missae, proprium missae (z zachowaniem podziału na de tempore i de sanctis), śpiewy wspólne, msze wotywne, index i sekwencje ${ }^{46}$.

Układ graduału rkp 7021 BUAM nie jest dokładnym odwzorowaniem rzymskiego modelu. Składa się z trzech zasadniczych części - proprium de tempore, ordinarium missce i sekwencji - oraz części zawierającej śpiewy na 23 niedziele okresu zwykłego, missa pro pace i mszę za zmarłych.

W tabeli 1 zestawione zostały układy trzech graduałów. Widać, że graduał potrydencki jest rozbudowaną formą graduału średniowiecznego. Rękopis z Biblioteki Uniwersyteckiej w Poznaniu nie zawiera wszystkich elementów graduale romanum. Jak wskazuje inskrypcja na karcie tytułowej: „pro dominicis per annum et festis solemnibus”, jest to część rzymskiego modelu przeznaczona na wszystkie niedziele roku i na święta

\footnotetext{
${ }^{43}$ Ibidem.

${ }^{44}$ Ibidem.

${ }^{45}$ Laus in Ecclesia..., s. 163-164.

${ }^{46}$ I. Pawlak, op.cit., s. 84.
} 
Tabela 1. Porównanie układu graduału średniowiecznego z graduałem rzymskim i rękopisem benedyktynek

\begin{tabular}{|c|c|c|c|c|c|}
\hline \multicolumn{2}{|c|}{ Graduał przedtrydencki } & \multicolumn{2}{|c|}{ Graduał potrydencki } & \multicolumn{2}{|c|}{ Graduał rkp 7021 BUAM } \\
\hline \multirow[t]{2}{*}{ proprium missae } & de tempore & \multirow{2}{*}{$\begin{array}{l}\text { proprium } \\
\text { missae }\end{array}$} & de tempore & \multirow{2}{*}{$\begin{array}{l}\text { proprium } \\
\text { missae }\end{array}$} & \multirow[t]{2}{*}{ de tempore } \\
\hline & de sanctis & & de sanctis & & \\
\hline \multirow[t]{2}{*}{ śpiewy wspólne } & $\begin{array}{l}\text { msze ku czci } \\
\text { świętych }\end{array}$ & \multirow[t]{2}{*}{$\begin{array}{l}\text { śpiewy } \\
\text { wspólne }\end{array}$} & $\begin{array}{l}\text { msze ku czci } \\
\text { świętych }\end{array}$ & & \\
\hline & msze wotywne & & & & \\
\hline \multicolumn{2}{|l|}{ ordinarium missae } & \multicolumn{2}{|c|}{ ordinarium missae } & \multicolumn{2}{|c|}{ ordinarium missae } \\
\hline & & \multicolumn{2}{|c|}{ msze wotywne } & & \\
\hline & & \multicolumn{2}{|l|}{ index } & & \\
\hline & & \multicolumn{2}{|c|}{ sekwencje } & \multicolumn{2}{|c|}{ sekwencje } \\
\hline & & & & \multicolumn{2}{|c|}{$\begin{array}{l}23 \text { niedziele okresu } \\
\text { zwykłego, missa pro pace } \\
\text { i msza za zmarłych }\end{array}$} \\
\hline
\end{tabular}

pańskie. Na podstawie powyższego porównania ksiąg można stwierdzić, że istniała także druga część graduału zawierająca śpiewy proprium de sanctis i pozostałe części, których nie ma w omawianym rękopisie.

Według tradycji trydenckiej korpus zasadniczy księgi tworzą śpiewy proprium missae $\mathrm{z}$ podziałem na proprium de tempore i proprium de sanctis ${ }^{47}$. Tak samo jest w przypadku rękopisu „poznańskiego”. W tej części księgi znajdują się śpiewy na: trzy niedziele Adwentu, Wigilię Bożego Narodzenia, msze w noc i dzień Bożego Narodzenia, święto św. Szczepana, Jana Ewangelisty i świętych Młodzianków, Wigilię Objawienia Pańskiego, Ofiarowanie, Objawienie Pańskie, trzy niedziele po Objawieniu, okres zwykły, Wielki Post, Niedzielę Palmowa, Triduum Paschalne, rezurekcję i msze w Niedzielę Zmartwychwstania, pięć niedziel po Wielkanocy, Wniebowstąpienie Pańskie, oktawę Wniebowstąpienia, Wigilię Zesłania Ducha Świętego, Zesłanie Ducha Świętego, święto Świętej Trójcy i Boże Ciało. W omawianym rękopisie nie zawarto śpiewów proprium de sanctis.

Śpiewy ordinarium missae rozpoczynają się od antyfon Asperges me i Vidi aquam ${ }^{48}$. Mimo że graduał rkp 7021 BUAM na początku zawiera część proprium missae, to całość rozpoczyna się właśnie antyfoną Asperges me. Antyfona Vidi aquam również nie została zapisana w części ordinarium missae, ale bezpośrednio przy uroczystości Zesłania Ducha Świętego, do której jest przypisana. Zaraz za nią umieszczono w całości antyfonę

\footnotetext{
47 Ibidem, s. 85.

${ }^{48}$ Ibidem, s. 84.
} 
Asperges me. Części stałe zostały zapisane w tradycyjnym układzie i przypisane do konkretnych niedziel i świąt.

W tym samym czasie, w którym powstał graduał benedyktynek toruńskich, drukowane były w Rzeczypospolitej graduały Piotrkowczyka. W tych księgach posłużono się zapisem na czterolinii, zaś w omawianym rękopisie użyto pięciolinii. Zarówno w drukach, jak i w manuskrypcie stosowano dwa rodzaje kluczy: C i F. Zasadniczą różnicę stanowi notacja. Piotrkowczykowie wykorzystali ogólnie przyjętą po soborze trydenckim notację gotycką. Jak podaje Pawlak, w zabytkach piotrkowskich występują neumy proste (punctum i virga), neumy pojedyncze (pes, clivis, scandicus, climacus, troculus i porrectus) oraz neumy bisoniczne (distropha i bivirga ${ }^{49}$ (tab. 2). Warto w tym miejscu przypomnieć, że notacja graduału rkp 7021 BUAM jest notacją prostą kwadratową.

Tabela 2. Obraz graficzny neum wykorzystanych przez Piotrkowczyka ${ }^{50}$

\begin{tabular}{|c|c|c|c|c|c|c|}
\hline Neumy proste & punctum & $\begin{array}{c}\text { virga } \\
\mathbf{0}\end{array}$ & & & & \\
\hline Neumy pojedyncze & $\frac{p e s}{\overline{\mathbf{a}}}$ & clivis & scandicus & climacus & troculus & porrectus \\
\hline Neumy bioniczne & $\begin{array}{c}\text { distropha } \\
-0 \\
\end{array}$ & 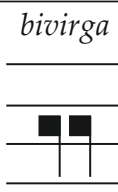 & & & & \\
\hline
\end{tabular}

Porównanie notacji w księgach Piotrkowczyka i w rękopisie benedyktynek kongregacji chełmińskiej wskazuje na prostotę tego drugiego. Możliwe jest, że zakonnice, które dopiero w klasztorze nauczyły się pisać i czytać, znały jedynie taką formę zapisu neumatycznego.

W graduałach piotrkowskich Pawlak opisuje układ proprium de tempore zabytków krakowskich. Warto porównać je z układem graduału benedyktynek (tab. 3).

Poza niewielkimi różnicami, jak brak Feria III rogationum w graduałach piotrkowskich, brak Feria $V$ w rkp 7021 oraz jednej niedzieli po Zesłaniu

${ }^{49}$ Ibidem, s. 88.

${ }^{50} \mathrm{~W}$ tabeli przedstawiono graficzne formy neum pochodzące z: Liber usualis, New York 1961, s. 11. 
Tabela 3. Układ proprium de tempore $\mathrm{w}$ graduałach piotrkowskich i graduale $\mathrm{rkp}$ 7021

\begin{tabular}{|c|c|c|}
\hline Okres liturgiczny & Graduały piotrkowskie & Graduał rkp 7021 BUAM \\
\hline \multirow{7}{*}{ Oktawa wielkanocna } & Dominica Resurrectionis & Dominica Resurrectionis \\
\hline & Feria II & Feria II \\
\hline & Feria III & Feria III \\
\hline & Feria IV & Feria IV \\
\hline & Feria $\mathrm{V}$ & Feria $\mathrm{V}$ \\
\hline & Feria VI & Feria VI \\
\hline & Sabbato in Albis & Sabbato in Albis \\
\hline \multirow{8}{*}{$\begin{array}{l}\text { Niedziele i święta } \\
\text { po Wielkanocy }\end{array}$} & Dominica in oct. Paschale & Dominica in oct. Paschale \\
\hline & Dom. II & Dom. II \\
\hline & Dom. III & Dom. III \\
\hline & Dom. IV & Dom. IV \\
\hline & Dom. V & Dom. V \\
\hline & & Feria III rogationum \\
\hline & In die Ascensionis & In die Ascensionis \\
\hline & Dom. Infra oct. Ascensionis & Dom. Infra oct. Ascensionis \\
\hline \multirow{7}{*}{$\begin{array}{l}\text { Oktawa Zesłania Ducha } \\
\text { Świętego }\end{array}$} & Dom. Pentecostes & Dom. Pentecostes \\
\hline & Feria II & Feria II \\
\hline & Feria III & Feria III \\
\hline & Feria IV & Feria IV \\
\hline & Feria $\mathrm{V}$ & \\
\hline & Feria VI & Feria VI \\
\hline & Sabbato & Sabbato \\
\hline $\begin{array}{l}\text { Niedziele po Zesłaniu } \\
\text { Ducha Świętego }\end{array}$ & 24 & 23 \\
\hline
\end{tabular}

Tabela 4. Układ Triduum Paschalnego w graduałach piotrkowskich i graduale rkp 7021

\begin{tabular}{|l|l|l|}
\hline \multirow{5}{*}{ Dzielkí } & \multicolumn{1}{|c|}{ Graduaty piotrkowskie } & Graduał rkp 7021 BUAM \\
\hline \multirow{5}{*}{ Wielki Piątek } & $\begin{array}{l}\text { obrzęd obmycia nóg - man- } \\
\text { datum }\end{array}$ & \\
\cline { 2 - 3 } & graduale: postquam surrexit & $\begin{array}{l}\text { graduale: } \text { Christus factus est } \\
\text { pro nobis }\end{array}$ \\
\hline & $\begin{array}{l}\text { tractus: Domine audivi / } \\
\text { eripe me }\end{array}$ & $\begin{array}{l}\text { tractus: Domine audivi / } \\
\text { eripe me }\end{array}$ \\
\cline { 2 - 3 } & $\begin{array}{l}\text { Adoracja Krzyża: } \\
\text { Ecce lignum crucis } \\
\text { Popule meus } \\
\text { Agios o theos }\end{array}$ & $\begin{array}{l}\text { Adoracja Krzyża: } \\
\text { Ecce lignum crucis } \\
\text { Popule meus } \\
\text { Agios o theos }\end{array}$ \\
\hline
\end{tabular}


cd. tabeli 4

\begin{tabular}{|l|l|l|}
\hline \multicolumn{1}{|c|}{ Dzień } & \multicolumn{1}{|c|}{ Graduały piotrkowskie } & Graduał rkp 7021 BUAM \\
\hline \multirow{2}{*}{ Wielki Piątek } & ant: crucem tuam & \\
\cline { 2 - 3 } & $\begin{array}{l}\text { responsorium: } \\
\text { Recessit pastor } \\
\text { Ecce quomodo } \\
\text { Sepulto Domino }\end{array}$ & \\
\hline Wielka Sobota & $\begin{array}{l}\text { Litania do Wszystkich } \\
\text { Świętych }\end{array}$ & $\begin{array}{l}\text { zapisane: Kyrie - Christe - } \\
\text { Kyrie }\end{array}$ \\
\hline Niedziela wielkanocna & procesja rezurekcyjna & \\
\hline
\end{tabular}

Ducha Świętego, oba układy są identyczne. W literaturze opisane zostały jedynie okresy wymienione $w$ tabeli. Pawlak nie poddał analizie Adwentu i okresu Wielkiego Postu.

Warto też zwrócić uwagę na śpiewy Triduum Paschalnego, ponieważ właśnie te dni stanowią centrum kalendarza Kościoła zachodniego (tab. 4).

W tej części księgi wykazują znaczne różnice. Ubogi okazuje się tu rękopis benedyktynek. Pawlak przytacza rozbudowane rubryki zapisane w typowych dla Triduum obrzędach, takich jak mandatum. W graduale "poznańskim” w ogóle go nie odnotowano. Z książki Borkowskiej można jednak dowiedzieć się, w jaki sposób benedyktynki obchodziły liturgię Wielkiego Czwartku. Obrzędy te były celebrowane tak samo jak w Rzymie ${ }^{51}$. Powstawały rękopiśmienne księgi, w których zawierano ryt na dane święto czy uroczystość. Jak podaje Borkowska, benedyktynki z Nieświeża podczas wielkoczwartkowej liturgii odgrywały barokowy dramat liturgiczny:

[...] śpiewać będzie Ewangelią u pultyna na to zgotowanego, na prawym rogu ołtarza: Sequentia Sancti Evangelii secundum Joannem: Ante diem... - jak we Mszy do końca. A gdy te słowa śpiewają: Surgit a coena, ksieni złoży płaszcz i przepasze się tuwalnią a tak zgotowawszy się do nóg umywania, czeka, aż skończą Ewangelią. Która, skoro siostra skończywszy, da ksieni całować; za tym ksieni zacznie: Mandatum novum..., chór weźmie śpiewać u pultyna w stronę chóru zgotowanego, a drugie siostry siedzą do umycia nóg $w$ miejscu $w$ chórze zgotowanym. Którym ksieni nogi umywa i całuje, a siostry, co służą do Mandatu, w miednicach czystą wodę dla każdej siostry na przemianę podawać będą. Gdy już ksieni skończy umywanie nóg siostrom, przeorysza stanie na miejscu, gdzie nogi umywają ${ }^{52}$.

${ }^{51}$ Wszystkie zagadnienia dotyczące obrzędów Wielkiego Tygodnia za: E. Borkowska, Życie codzienne polskich klasztorów żenskich XVII-XVIII wieku, Warszawa 1996, s. 264.

${ }^{52}$ Ibidem, s. 267. 
Później następował śpiewany dialog Jezusa i świętego Piotra. Składał się on z antyfon i responsoriów chóralnych. Po zakończeniu obrzędu śpiewano hymn Ubi caritas.

W liturgii wielkopiątkowej w porównywanych graduałach identyczna jest Adoracja Krzyża oraz naprzemienne śpiewy Popule meus - Agios o Theos. W rkp 7021 BUAM nie zapisano antyfony Crucem tuam oraz śpiewów responsorialnych Recessit pastor, Ecce quomodo i Sepulto Domino. Tam, gdzie w graduale piotrkowskim występuje pełna Litania do Wszystkich Świętych, w toruńskim rękopisie zapisane zostało wezwanie Kyrie eleisonChriste eleison - Kyrie eleison. Pozwala to przypuszczać, że w tym miejscu również wykonywano całą litanię, nie została ona jednak zapisana w księdze. U Piotrkowczyka wydrukowano śpiewy na procesję rezurekcyjna, których nie zawarto w rkp 7021 BUAM.

Rękopis benedyktynek jest księgą dużo uboższą od druków Piotrkowczyków. Te drugie zawierają także rodzimą tradycję diecezji krakowskiej, o czym pisze Pawlak. Można przypuszczać, że benedyktynki nie umieściły wielu rytów, litanii i śpiewów w tym graduale, ponieważ zapisywały je w innych księgach, podobnie jak śpiewy proprium de sanctis. Nie wiadomo dokładnie, z jakiego źródła korzystały skryptorki, spisując ową księgę. Prawdopodobnie uzyskały od biskupa, pod którego obediencją się znajdowały, jakiś wzorzec rzymski. Można przypuszczać, że w momencie wprowadzania reform na każdą diecezję przypadała kopia rzymskich ksiąg.

Graduał rkp 7021 BUAM jest jednym z wczesnych śladów wprowadzania reformy trydenckiej na terenie ówczesnej Rzeczypospolitej. Świadczy o głębokim zaangażowaniu benedyktynek kongregacji chełmińskiej w dbałość o liturgię i jej oprawę muzyczną.

\section{Podsumowanie}

Dla liturgii Kościoła zachodniego najważniejszym osiagnięciem reformy potrydenckiej było wprowadzenie ujednoliconych ksiąg liturgicznych, co prowadziło do unifikacji liturgicznej całego Kościoła. W Rzeczypospolitej przyjęto brewiarz i mszał rzymski oraz mające z nimi ścisły związek antyfonarz i graduał. W księgach tych starano się jednak zachowywać tradycje lokalne, co nie pozwoliło na pełne przyjęcie rytu rzymskiego.

Graduał rkp 7021 BUAM, pochodzący z toruńskiego skryptorium zakonu benedyktynek kongregacji chełmińskiej i będący przykładem wprowadzania przez zakonnice reformy trydenckiej na terenie XVII-wiecznej Rzeczypospolitej, nie ma powiązania z tradycją lokalną czy zakonną. 
Uniemożliwia je zawarty w całości rękopisu rzymski układ proprium de tempore. Przypuszczalnie śpiewy w języku polskim czy antyfony nawiązujące do tradycji zakonnej mogły być zawarte w części proprium de sanctis. Jest to jednak hipoteza niemożliwa do potwierdzenia, ponieważ owa księga nigdzie się nie zachowała.

W historii recepcji reformy trydenckiej na terenie Rzeczypospolitej benedyktynki kongregacji chełmińskiej mają niewątpliwie wiele zasług. Odcinając się od reguły benedyktynów tynieckich i tworząc własną, opartą na postanowieniach soboru trydenckiego, okazały się zakonem nowatorskim i atrakcyjnym. Nie bez znaczenia jest ich współpraca z zakonem jezuickim, który także był propagatorem reformy liturgicznej.

W celu kontynuacji badań i poszerzenia wiedzy na temat recepcji reformy trydenckiej warto poświęcić uwagę badaniom źródłowym. W literaturze brak danych na temat wzorców rzymskich. Nie wiadomo, skąd i od kogo benedyktynki kupowały druki czy rękopisy, z których potem przepisywały własne księgi. Jest to kwestia interesująca i warta zgłębienia.

Dbałość o tradycje trydenckie w Polsce jest wciąż podtrzymywana. Zakres wiedzy historycznej i liturgicznej jest kompletny. W wielu miejscach powraca się do sprawowania liturgii trydenckiej. Duchowieństwo wykazuje też troskę o teoretyczne przygotowanie wiernych biorących udział w nabożeństwach sprawowanych w rycie rzymskim.

Kwestia muzyki liturgicznej z tamtego okresu, w szczególności chorału gregoriańskiego, budzi wiele kontrowersji, zwłaszcza wśród przedstawicieli szkoły solesmeńskiej. Uważają oni, że śpiewy chorałowe po soborze trydenckim zostały zubożone i straciły swoją różnorodność. Zwolennicy odnowy liturgicznej popierają reformę chorału ze względu na ujednolicenie liturgii, a co za tym idzie - także muzyki liturgicznej.

Niewątpliwie po soborze trydenckim melodie chorałowe zostały uproszczone i zunifikowane. Nie należy jednak porzucać badań nad chorałem gregoriańskim okresu potrydenckiego. Wprowadzenie tak wielkich reform w zakresie liturgii jest bowiem niezwykle ważne dla historii muzyki zachodniej, a zwłaszcza dla monodii liturgicznej. Wciąż istnieje wiele nieprzebadanych druków i rękopisów muzyczno-liturgicznych, interesujący jest również proces przyjmowania reform przez parafie i zakony polskie. Nieznane są konkretne rzymskie źródła, z których korzystali skryptorzy. Z prowadzonych badań wyłania się historia polskiej muzyki kościelnej XVII wieku, zarówno chorału gregoriańskiego, jak i polifonii sakralnej. Znane są też dokumenty wystosowywane przez papieży, takie jak Annus qui53, które dawały wyraźne dyrektywy dotyczące

${ }^{53}$ Encyklika papieża Benedykta IV, wydana w 1749 roku. 
oprawy muzycznej nabożeństw, jednak nie znajdowały odzwierciedlenia w praktyce wykonawczej. Jest to kolejny istotny wątek, warty zgłębiania przez badaczy.

\section{Bibliografia}

Bobrowska J., Kultura muzyczna w świetle literatury staropolskiej XVI i XVII wieku, „Muzyka” 1977, nr 2.

Borkowska M., Życie codzienne polskich zakonów żeńskich XVII-XVIII wieku, Warszawa 1996.

Gieburowski W., Chorat gregorjański w Polsce od XV do XVII wieku ze specjalnym uwzględnieniem tradycji i reformy oraz chorału piotrkowskiego, Poznań 1922.

Hinz E., Chorał gregoriański, Pelplin 1999.

Izbicki B., Trzy bitwy o chorat gregoriański, http://www.academia.edu/6219818/ Trzy_bitwy_o_choral_gregorianski.

Korytkowski J., Arcybiskupi gnieźnieńscy, prymasowie i metropolici polscy od roku 1000 aż do roku 1821, czyli do połaczenia arcybiskupstwa gnieźnieńskiego z biskupstwem poznańskiém. Według źródeł archiwalnych, t. 3, „Kuryer Poznański” 1889.

Laus in Ecclesia. Szkoła śpiewu gregoriańskiego, Dębogóra 2013.

Pawlak I., Graduały piotrkowskie jako przekaz chorału gregoriańskiego w Polsce po Soborze Trydenckim, Lublin 1988.

Przybyszewska-Jarmińska B., Barok. Część 1, 1595-1696, Warszawa 2006.

Siekierka I.H. OFM, Notacja sangalleńska i metzeńska jako wspótczesne źródło interpretacji chorału gregoriańskiego, Opole 2005.

Sczaniecki P. OSB, Msza po staremu się odprawia, Kraków 1967.

Sczaniecki P. OSB, Służba Boża w dawnej Polsce. Studia o Mszy Św., seria 2, Poznań 1966.

Stelmachowska B., Sztuka ludowa na Kaszubach, Poznań 1937.

Szołdrski W., Kronika benedyktynek chełmińskich, Pelplin 1937.

Walter-Mazur M., Figura i fraktem. Kultura muzyczna polskich benedyktynek w XVII i XVIII wieku, Poznań 2014.

Walter-Mazur M., Music in the Benedictine Nunneries in Chetmno and Torun after the Post-Tridentine Reform, w: Musica Baltica. The Music Culture of Baltic Cities in Modern Times, red. J. Woźniak, Gdańsk 2010.

The liber usualis, New York 1961.

The New Grove Dictionary of Music and Musicians, t. 18, Oxford Univercity Press.

Strony internetowe

http://mszatrydencka.waw.pl/index.php/msza-trydencka/zrubryk [dostęp: 4.03.2014]. http://soborowa.strefa.pl/code-21/ [dostęp: 12.03.2014].

http://www.documentacatholicaomnia.eu/04z/z_1545-1563_Concilium_Tridentinum_Documenta_LT.doc.html [dostęp: 8.04.2014]. 


\section{Gradual, MS 7021, from the Medieval and Renaissance Manuscripts Section of Poznań University Library, as an example of post-Trent reception and implementation of Georgian plainchant in Polish liturgical celebration}

Aвstract. The gradual MS 7021 (kept at Poznan University Library) is one of the earliest examples of the reception of post-Trent reform of Gregorian plainchant in the seventeenth century Poland. The volume comes from the scriptorium of Benedictine convent in the Chełmno congregation.

The article's aim is to present the liturgical alterations and changes that occurred in the Polish Republic in the early seventeenth century with the example provided by an analysis of the content of the Benedictine manuscript as well as other available sources. Additionally, the article examines the problem of the reform of the Georgian repertoire introduced by the Apostolic See and the its subsequent reception in Poland.

In the liturgy of the Western World, the most significant outcome of the postTrent reform was the introduction of standarised principal liturgical books, which in consequence led to a unification of liturgy in the whole of the Church's life. The Polish-Lithuanian Commonwealth adopted the breviary and the Roman Missal, the liturgical book that contains the texts and rubrics for the celebration of the Mass in the Roman Rite of the Catholic Church, as well as the antiphonary and gradual. Local traditions, however, were attempted to be retained in these liturgical books, so that the proper Roman rite could not have been implemented to the full. However, the gradual, MS 7021 BU UAM, from the Torun scriptorium of the Benedictine convent, is an example of the implementation the Trent reform in the seventeenth century Polish-Lithuanian Commonwealth that has no connections with any local or locallybased monastic tradition.

The Benedictine nuns from the Chełmno congregation were undoubtedly prominent in the history of the Trent reform in the Republic of Both Nations. By dissenting from the spirit of St. Benedict's rule professed by the Tyniec Benedictines, and by creating their own rule based on the resolutions of the Council of Trent, the convent adopted an innovative and attractive stance. The cooperation of the nuns with the Jesuits from the Society of Jesus, who were also promoters of the liturgical reform, was also instrumental.

The article shows how important it is to carry on with research studies on Polish music and liturgical sources from the post-Trent period. The article is also an important contribution to the investigation and description of a source that, as yet, has not been satisfactorily addressed.

Key words: gradual, Trent reform, the Council of Trent, Georgian chant, Catholic Church, liturgy of the Catholic Church, rites, antiphonary, missal, breviary, Piotrkowczyk, Benedictine nuns of the Chełmno congregation, manuscript, the seventeenth century. 